\title{
EchoGéo
}

$19 \mid 2012$

Du littoral à la haute mer : quelles recherches récentes en géographie?

\section{From the coastline to the open sea: recent research in geography}

Annual meeting of the Commission de géographie de la mer, du littoral et des îles of the Comité National Français de Géographie, Institut

Universitaire Européen de la Mer, Brest, June 2011

\section{Lydie Goeldner-Gianella}

\section{OpenEdition}

\section{Journals}

Édition électronique

URL : https://journals.openedition.org/echogeo/13094

DOI : 10.4000/echogeo.13094

ISSN : 1963-1197

Éditeur

Pôle de recherche pour l'organisation et la diffusion de l'information géographique (CNRS UMR 8586)

Référence électronique

Lydie Goeldner-Gianella, «From the coastline to the open sea: recent research in geography », EchoGéo

[En ligne], 19 | 2012, mis en ligne le 09 mai 2012, consulté le 10 août 2021. URL : http://

journals.openedition.org/echogeo/13094; DOI : https://doi.org/10.4000/echogeo.13094

Ce document a été généré automatiquement le 10 août 2021.

EchoGéo est mis à disposition selon les termes de la licence Creative Commons Attribution - Pas d'Utilisation Commerciale - Pas de Modification 4.0 International (CC BY-NC-ND) 


\section{From the coastline to the open sea: recent research in geography}

Annual meeting of the Commission de géographie de la mer, du littoral et des îles of the Comité National Français de Géographie, Institut Universitaire Européen de la Mer, Brest, June 2011

\section{Lydie Goeldner-Gianella}

1 The growth of population and human activity in coastal environments, as well as the level of erosion and coastal flooding, which is liable to worsen due to climate change, means that research on the sea and the coastline is becoming ever more necessary and socially useful. Through such research a variety of issues can be addressed, in the areas of defense and economics as well as ecology, society, and natural heritage. Since these issues are analyzed conjointly, it seems worthwhile to bring together geographers specializing in coastal research, but from different backgrounds and with different perspectives and specializations within the field, for an annual meeting.

2 The "Commission de géographie de la mer, des côtes et des îles" - an offshoot of the Comité National Français de Géographie - was created for this purpose some decades ago. The Commission now meets over two days once a year for theoretical and practical sessions, that is to say, presentation of scientific papers and field trips. Its work often continues beyond these annual meetings, resulting in joint publications and the development of joint research programs. This Commission is in effect a site for encounters, exchanges, and regular discussions among French geographers who specialize in coastal areas. The value of these annual exchanges, conducted outside the more academic framework of scientific research, is worth emphasizing. They are useful both for sustaining this branch of geography and for their global perspective on coastal areas and the diverse range of issues that affect them. Following the meetings held in recent years in Bordeaux, Perpignan, Dinard, Saint-Valery-sur-Somme, and Marseilles, it was the turn of the coastal area specialists from the Institut Universitaire Européen de la Mer (IUEM) - especially Louis Brigand, professor of coastal geography - to host the Commission in Brest on June 26 and 27, 2011. 
3 The first day was devoted to an informative and enjoyable tour of the island of Molène. This field trip included a some presentations: Pierre Stéphan gave a talk on geoarchaeology and Louis Brigand discussed tools for the protection and conservation of the islands and islets of the archipelago (Figures 1 and 2).

Figure 1 - View of the island of Molène from the islet of Lédénez Vraz

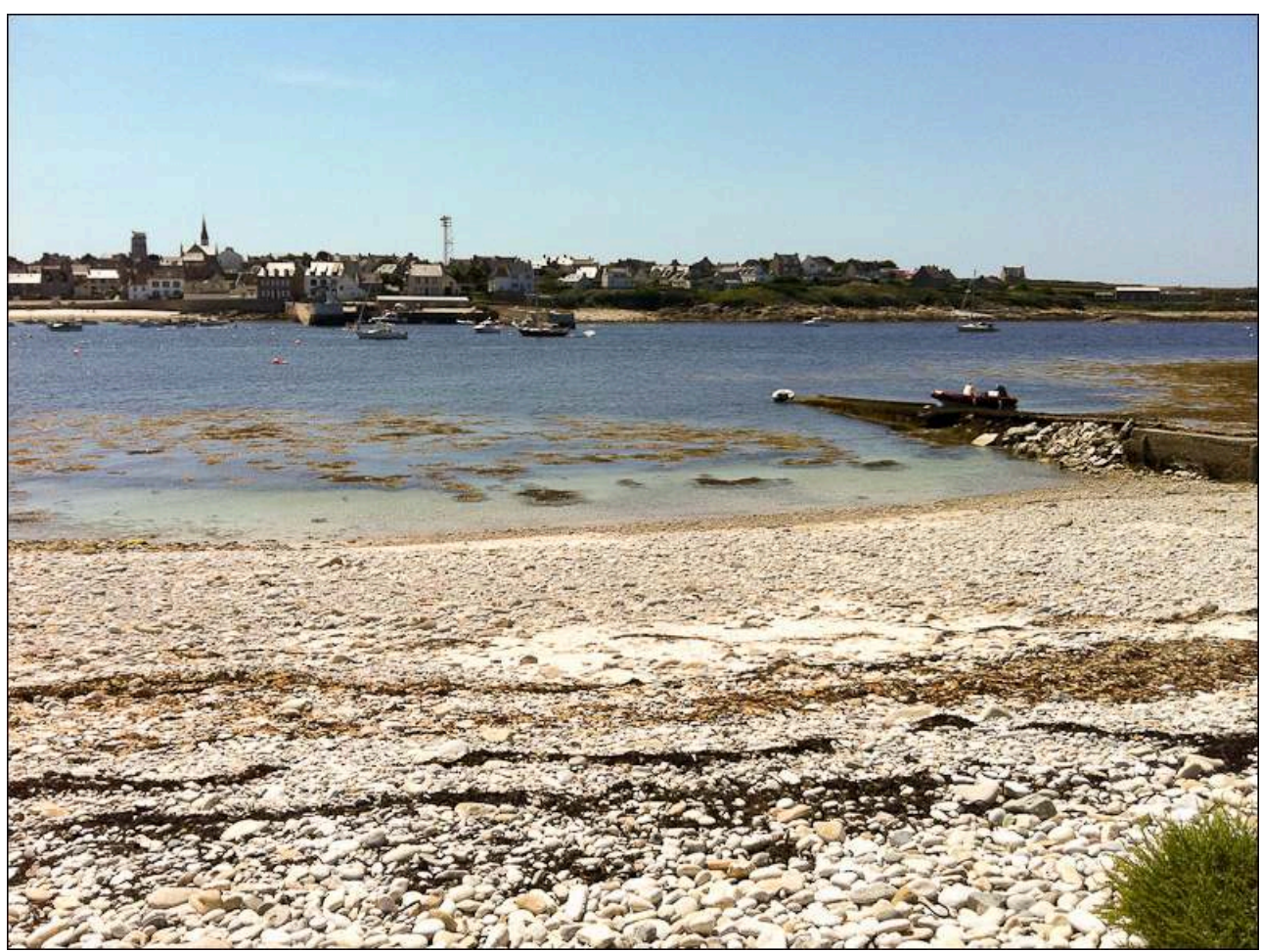

Photo: Lydie Goeldner-Gianella, 2011. 
Figure 2 - A multi-generational group of geographers on a field trip

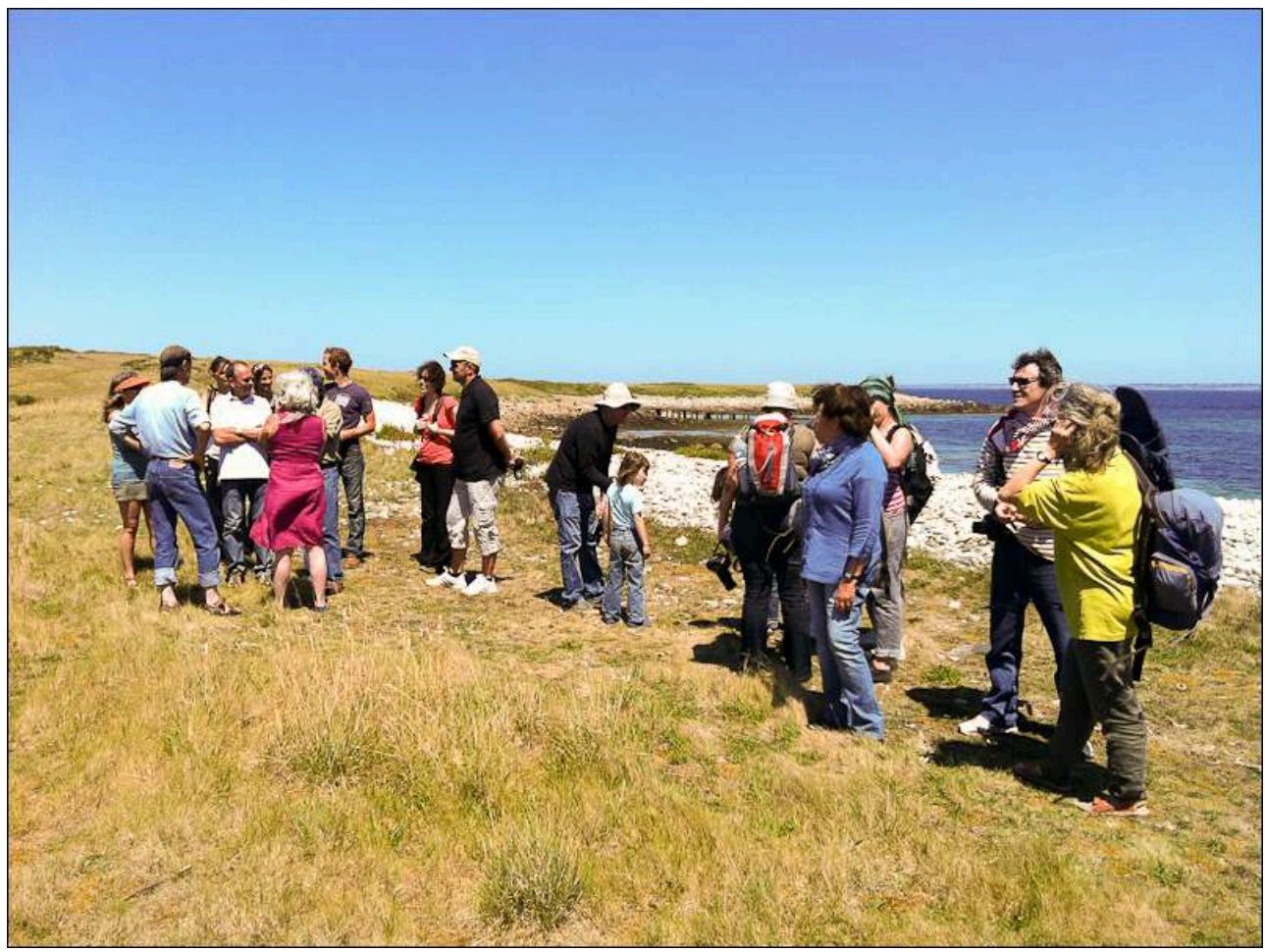

Photo: Lydie Goeldner-Gianella, 2011

The second day of the meeting was organized around three questions:

- What recent trends and possible lacunae characterize research in France, with respect to the major issues affecting the coastline and the sea both in France and elsewhere?

-. What recent developments have there been in methods and investigation techniques in coastal geography?

- What is the operational capacity of this research, and what are its concrete applications, now and in the future?

These three questions were used to group the twenty or so presentations into five topics (see the conference program appended). The first of these focused on the observation and understanding of natural coastal dynamics. The second was devoted to some new issues in the field of coastal geography, namely coastal heritage and coastal landscapes, including a discussion of the landscapes of the Mascarene archipelago, underwater landscapes, coastal forest landscapes, and the maritime cultural heritage. The papers of the third section addressed the issue of tourism. A longstanding topic, today it presents new challenges, such as visitor management in especially popular areas and the incorporation of sustainable development, that call for further discussion and new methods. The fourth session dealt with use and risk management. The presentations addressed changing uses including recreational fishing and seaweed farming; the perceptions and responses of local populations undergoing major changes, including the establishment of protected marine areas or the expansion of depolderization; and familiar or newly intensifying hazards in coastal areas, such as infectious diseases. The papers of the fifth session were concerned with maritime space, an area apparently of particular interest to the younger generation of 
geographers and historians, to judge by the number of theses being written on the subject.

Several subjects were brought up repeatedly in the presentations, giving a picture of current trends in research on coastal geography. Natural coastal environments and their dynamics are discussed from new perspectives: geographers today are interested in their environmental vulnerability, through studies of climate change and sustainability. They also address the issue of the ecosystem services that coastal biodiversity, in all its forms, can provide; for instance, Yves Petit-Berghem discusses what might happen when a state-owned nature reserve in an area of moving dunes is opened to the public. Geographers are also investigating hitherto unexplored landscapes, those of the seabed and the open sea. In social geography, research on coastal areas now focuses on load-bearing capacity, social approval, cultural heritage, and the links between development and environment, for example in studies of protected marine areas and of new methods of risk management. In this issue, Sophie Litzler takes us to the Far East, discussing the potential of seaweed farming in coastal China as well as its natural, environmental, and social constraints in a context of extreme pollution, rapid economic development, and competition for space. Research on coastal hazards is taking social and environmental vulnerability into consideration to a greater extent. Thus in the section "Sur l'image," Annaïg Oiry stresses the value of a study of social perception of hazards on the Ile de Sein in order to understand how it is possible to live with hazards but also make use of hazards. All these research projects highlight the increased tensions between environment and development in coastal spaces and societies (see the first part of this dossier).

7 In parallel, maritime space is increasingly attracting the attention of researchers in social as well as cultural and geopolitical fields (see the second part of the dossier). The historian Nicolas Cochard contributes an article on the history of seafaring people, using the example of Le Havre to show how their geographical origins and intra-urban locations have changed in modern times, especially as a result of the modernization of the shipping industry. Nora Mareï analyzes the role played by the globalization of the shipping industry in the spatial, territorial, and environmental changes taking place in the Straits of Gibraltar, a maritime space undergoing both radical change and integration. Lastly, Camille Parrain takes us out to sea, where human geographers have rarely ventured even though the ocean now seems to have become one component of human social space. Research into the social geography of the ocean, until now divided up by region or sector, is exploring ever more structured maritime landscapes and territories, for example through studies of travel by sailboat.

In the area of methodology, in a time of increasing coastal development and climate change we can also note the growing role played by coastal observatories, often staffed by geographers, in the monitoring of natural dynamics, landscapes, and human use (see the third part of the dossier). Thus Serge Suanez et al. address the topic of coastal observatories in France, which function as essential monitoring tools for risk management and decision-making. They draw up a list of French observatories and provide an overview of their operations and data, then give a detailed description of the Observatoire du Domaine Côtier of the IUEM in Brest. Nicolas Le Corre et al. raise the question of how to study and monitor human use of coastal, marine, and island areas. Following an overview and analysis of methods for studying recreation and tourism in France, the group shows how these data can be used to the improve 
observation of human use of coastal areas, which would benefit from greater organization and expansion.

The eight articles presented in this issue seem to us to give a good account of the diversity of ongoing research on coastal, marine, and island areas being conducted both by young $\mathrm{PhD}$ students and graduates and by existing groups specializing in coastal topics, such as those of the Géomer laboratory and the IUEM who hosted our meetings. This research is fully in tune with the current demands of the government. ${ }^{1}$ It currently focuses on links between land and sea, especially via the connection between (coastal) blue-green and (deep-sea) navy blue waters. The government is also concerned for the future, in the context of coastal development and climate change already mentioned, with the effective governance of coastal and maritime areas, and with future strategies for planning and protection, both on land and sea. This concern can be summarized in a question that is easy to ask but less easy to answer: "What will the coastlines of tomorrow look like?"2 This is the kind of question that scientists are now being asked, but it is not merely a physical or technological question; its scope more broadly covers "knowledge, practices, visions and perceptions." ${ }^{3}$ The attention that geographers pay not only to coastal areas but also to the sea in all its facets, as well as their interest in biodiversity, environmental hazards and constraints, and the most sustainable ways of managing them, will surely help to respond to these political and social concerns.

The next meetings of the Commission de géographie de la mer, du littoral et des îles will be organized jointly with the Commission de biogéographie of the CNFG and the UMR PRODIG 8586 research unit, and be held in the Bassin d'Arcachon in late June 2012. Topics will include coastal wetland environments and fluctuations in methods of coastal risk management, contrasting traditional heavy-handed methods of protection with new "soft" methods that make use of the natural environment.

\section{NOTES}

1. Cf. the most recent call for projects of the MEDDTL Programme Liteau (January 2012) and that of the Fondation de France (2011/2012).

2. Cf. the Fondation de France $2011 / 2012$ invitation to tender.

3. Idem.

INDEX

Thèmes : Sur le Champ - Sur le Terrain 


\section{AUTEUR}

\section{LYDIE GOELDNER-GIANELLA}

Lydie Goeldner, Lydie.Goeldner-Gianella@univ-paris1.fr, is a lecturer (HDR) at the University of Paris 1 Panthéon-Sorbonne and a member of the UMR 8586 PRODIG CNRS research unit. Recent publications include:

- Goeldner-Gianella L., forthcoming. Dépoldériser en Europe occidentale. Pour une géographie et une gestion intégrées du littoral.Paris: Publications de la Sorbonne.

- Goeldner-Gianella L., Feiss-Jehel C., and Decroix G., 2011. Les oubliées du "désir du rivage"? L'image des zones humides littorales dans la peinture et la société françaises depuis le XVIIIe siècle. Cybergéo (http://cybergeo.revues.org/23637;DOI:10.4000/cybergeo.23637).

- Goeldner-Gianella L., 2010. Quelle place pour la géographie dans les études environnementales? L'Espace Géographique, No. 4, pp. 289-294. 